\title{
A Core On The Edge: An Urban Bird Assemblage On The Atlantic Margin Of Europe
}

Jason David Luscier ( $\square$ lusciejd@lemoyne.edu )

Le Moyne College https://orcid.org/0000-0003-0280-2579

\section{Research Article}

Keywords: urban ecology, bird density, species richness, avian communities, Irish birds, Cork City

Posted Date: April 27th, 2021

DOl: https://doi.org/10.21203/rs.3.rs-416772/v1

License: (9) This work is licensed under a Creative Commons Attribution 4.0 International License. Read Full License 
A core on the edge: an urban bird assemblage on the Atlantic margin of Europe

Jason D. Luscier

Department of Biological and Environmental Sciences, Le Moyne College, 1419 Salt Springs Road, Syracuse, New York, USA

\section{E-mail address: lusciejd@lemoyne.edu}

\section{Acknowledgments}

I thank Dr. Tom Kelly with the University College Cork (UCC) for consulting on the survey design stage of this study as well as for reviewing earlier drafts of this paper. I also thank Dr. John Quinn and the School of Biological, Earth and Environmental Sciences at UCC for providing useful advice along the way as well as office space and library access. I thank the following Le Moyne College programs for funding this project: O’Leary International Travel Grants Program, Research and Development Committee, and the Center for Urban and Regional Applied Research. 


\begin{abstract}
:
Urbanization threatens bird populations globally, however many urban habitats present important refugia for wildlife in this rapidly changing landscape. Additionally, birds at the periphery of their global range are more prone to landscape changes and thus these distributions are good indicators of the effects of urbanization on diversity; e.g., bird populations and communities of Cork City, Ireland. The aim of this study was to evaluate effects from urbanization on bird densities (birds/ha), species richness, and species composition throughout Cork City. I surveyed 32 points selected with a stratified random sample within commercial areas, residential habitats, and green spaces throughout Cork City during four breeding seasons between 2016-2019. Species richness was highest in green spaces with 18-34 species; whereas residential habitats had 14-27 species and commercial areas had 9-20 species. The most densely populated species citywide were Rock Pigeons (5.4-9.1 birds/ha), Eurasian Jackdaws (2.9-3.8 birds/ha), Rooks (4.5-6.4 birds/ha), European Starlings (3.4-5.3 birds/ha), Eurasian Blackbirds (2.4-3.6 birds/ha), and House Sparrows (2.7-4.5 birds/ha). Overall a lack in urban green space surrounding survey points was most strongly associated with reduced species richness and population estimates. Also, both species richness and population densities tended to be higher in regions with less noise pollution and farther from the urban core. Ultimately these results corroborate other studies stressing the importance of urban green spaces for conserving biodiversity in cities. This is particularly important for the birds of Cork City given that these urban habitats are at the western edge of these species' distributions.
\end{abstract}

\title{
Keywords:
}

urban ecology, bird density, species richness, avian communities, Irish birds, Cork City 


\section{INTRODUCTION}

Most bird species in Ireland are at the western most periphery of their European distributions (Billerman et al. 2020). These island isolated populations are smaller than their mainland counterparts and likely respond differently to environmental change (Fuller et al. 2007). Populations of $74 \%$ of Ireland's bird species are stable or increasing and $26 \%$ are in decline (Lewis et al. 2019). Specifically, some species that are common across continental Europe have shown declines in Ireland in recent decades (e.g., Common Swifts [Apus apus], European Robins [Erithacus rubecula], and Eurasian Magpies [Pica pica; Crowe et al. 2010], whereas Eurasian Wrens (Troglodytes troglodytes) and Common Wood-pigeons (Columba palumbus) have relatively high population levels in Ireland compared with other parts of their range on the European mainland (Crowe et al. 2014). These differences in relative abundances likely result in different bird assemblages in Ireland versus mainland Europe; therefore, it is important to not initiate conservation strategies in Ireland based on data gathered in mainland Europe. It is critically important to understand how Ireland's isolated and peripheral bird populations and communities respond to anthropogenic activities such as urbanization in order to inform future conservation strategies.

The main objective of this study was to evaluate the effects of urbanization on bird populations and communities in Cork City, Ireland with the aim of supplying conservationfocused recommendations for future urban planning programs for the city. Similar studies have been done elsewhere (Beninde et al. 2015, Biroli et al. 2020, Jokimäki et al. 2016, Loss et al. 2009, Marzluff 2001, Strohbach et al. 2009), however geographically (i.e., city-) specific research is essential for informing urban conservation (Nilon et al. 2017). To attain this goal, I surveyed breeding birds throughout the city for four years and measured a suite of habitat 
variables that might explain patterns in three response variables: (1) bird population densities (birds/ha), (2) species richness (\#'s of species), and (2) species composition (i.e., percentage of species overlap). These response variables were evaluated throughout Cork City in commercial regions (i.e., gray spaces), residential areas, and managed habitats (e.g., green spaces). This research is necessary for informing conservation of urban birds in Ireland, specifically Cork City - the fastest growing urban areas in Ireland and one of the fastest growing metropolitan regions in all of Europe (Department of Housing, Planning and Local Government 2017).

Global urbanization has resulted in increased habitat heterogeneity across the landscape (Pickett et al. 1997). While many generalist bird species have responded positively to these increases in habitat heterogeneity, most populations have suffered. Cities often lack adequate habitat for local wildlife and do not function optimally as a network of communities (i.e., ecosystem services do not function efficiently; Marzluff 2001). However, many bird species have shifted their distributions into cities to take advantage of novel habitats with reduced predation (Samia et al. 2017) and increased access to food (albeit of questionable quality; Marzluff 2001). Consequently, cities often have higher levels of diversity compared with local natural spaces (Rebele 1994); however, this may not be true in cities at the periphery of species' distributions. Therefore, it is important to understand how urban variables affect Cork City bird populations and communities in order to inform future conservation strategies.

Two important variables likely affecting urban bird distributions are availability of green space (Soanes and Lentini 2019) and socioeconomic factors (Dow 2000; Kinzig et al. 2005; Melles 2005; Loss et al. 2009; Strohbach et al. 2009). Urban green spaces tend to have higher species richness than surrounding areas (Andersson et al. 2014, Dale 2018, Donnelly and Marzluff 2004, Jokimäki et al. 2014, Korányi et al. 2020, MacGregor-Fors et al. 2016); however, 
regions surrounding urban green spaces tend to have higher bird diversity and abundance due to increased habitat availability (Soanes and Lentini 2019). Additionally, more affluent neighborhoods may have more biodiverse gardens, bird feeders, and manicured green spaces compared with less affluent locations. While these neighborhoods may be dominated by nonnative vegetation, they typically have greater diversity in habitat structure (i.e., a heterogeneous mix of herbs, shrubs, and trees; Hope et al. 2003). Also, some neighborhoods may have better trash management programs and thus fewer scavenging species (Preininger et al. 2019). Specifically, neighborhoods with higher densities of humans (e.g., multi-family homes and apartment complexes) have more trash to manage and thus likely have increased numbers of opportunistic animal species (e.g., corvids; Vuorisalo et al. 2003; Withey and Marzluff 2008). Few studies have evaluated variations in wildlife distributions by these factors.

I hypothesized that generalist bird species would have relatively high population densities in commercial regions of the city, but that these species also occur in both residential and managed areas. Also, it was reasonable to expect the densities of most species to be highest in managed habitats, and that the amount of vegetational cover, proximity to water, proximity to wooded areas, and more affluent neighborhoods would have positive effects on species richness. I predicted that managed habitats would differ the most in species composition given that these areas tend to have greater habitat structure and thus increased habitat availability, supporting a wider array of species.

\section{METHODS}

\section{Study area}


Cork City is $\sim 3,960$ ha in County Cork on the southern coast of Ireland (Figure 1). Cork City is the second largest city in Ireland with 125,657 inhabitants (Central Statistics Office 2016b). On 31 May 2019 Cork City expanded its boundary to 18,700 ha, adding $\sim 85,000$ humans (Cork City Council 2019); however, this study started prior to this expansion and so inference can be made only on the 3,960-ha area depicted in Fig 1. Cork City land area is comprised of 12\% commercial, 25\% managed, and 63\% residential urban zones (GIS data from the Department of Housing, Local Government and Heritage 2020). Cork City is relatively monocentric as is apparent by the large commercial region located at the geographic center of the city. Commercial regions include shopping centers, industrial parks, etc. Managed zones include green spaces like city parks, college campuses, cemeteries, etc. Residential zones include neighborhoods with single-family and/or multi-family housing.

Cork City is situated within a greatly altered landscape. The island of Ireland is fragmented into $\sim 66 \%$ agriculture and only $\sim 10 \%$ forested land (based on 2006 land cover data as analyzed by Biodiversity Information System for Europe 2020). Specifically, County Cork is comprised of $12 \%$ forested land and has the largest forest area in the country (90,020 ha), but a majority of this is stocked with conifers for logging (Department of Agriculture, Food and the Marine 2020). Native trees in County Cork include ash (Fraxinus spp. L.), oak (Quercus spp. L.), and birch (Betula spp. L.); these species occur sparsely throughout Cork City (Mundy 2014). The most common trees in Cork City include non-natives to Ireland such as sycamore (Acer pseudoplatanus L.), beech (Fagus sylvatica L.), horse chestnut (Aesculus hippocastanum L.), and Douglas fir (Pseudotsuga menziesii [Mirb.] Franco; National Biodiversity Data Centre 2020). 


\section{Data collection}

Bird surveys. I surveyed breeding birds from May through June during four years (2016-2019) at 32 points selected with a systematic random sample among commercial, residential and managed habitats. I used a power analysis with bird detection data collected from a series of pilot surveys to estimate an adequate number of survey points for obtaining density estimates with coefficient of variation of $20 \%$ for each habitat category (Buckland et al. 2001). This resulted in nine points in commercial habitats, 11 points in residential habitats, and 12 points in managed habitats.

Bird surveys occurred from 06:00 to $13: 00$ on days with no rain and minimal wind $(<20$ kph) for optimal bird availability and detectability (Martin et al. 1997). During each 10-min survey I recorded species, numbers of individuals, and distances to each detection within $100 \mathrm{~m}$ of the survey point. Distances were measured with a Nikon ${ }^{\circledR}$ Forestry Pro $\subset$ laser rangefinder. I used a sound meter to record the average urban noise level $(\mathrm{dB})$ throughout each 10-min survey. Twenty-four points were surveyed once a year for a total of four surveys each. Three points were surveyed a total of five times (twice during 2016) and five points were surveyed only three times total due to high levels of precipitation during 2019 (and thus these points were not surveyed that year).

Habitat variables. I measured nine survey- and site-specific habitat variables that might best explain patterns in bird densities, species richness, and species composition among the three habitat types (Table 1). Information was amassed from the peer-reviewed literature (the sources used for informing each variable are identified in the Table 1) to determine the most parsimonious (and logistically feasible) list of variables to measure. Many studies throughout the world have reported that habitat area and vegetational structure are important variables in determining urban diversity (Beninde et al. 2015). Therefore, I estimated area of gray space and 
area of woody vegetational cover within 100-m of each point (the distance within which bird detections were recorded). These habitat variables were included in candidate models explaining bird densities and species richness.

\section{Data analysis}

Principal components analysis. I conducnted a principal component analysis (PCA) with package 'factoextra' (Kassambara and Mundt 2020) in R 3.6.2 (R Core Team 2019) to evaluate relationships among the nine habitat variables and the raw count data for each species. I used this approach to consider meaningful groups of variables in model construction and to eliminate from further analyses any habitat variables with minimal contribution to the variation in the data (James and McCulloch 1990). This aided in the construction of parsimonious candidate models for explaining density and species richness, respectively (explained below). Specifically, I used variables from the first two dimensions in the PCA in further analyses. Dimension 1 variables and dimension 2 variables, respectively, were combined in density and species richness models. Variables with minimal contribution to these first two dimensions were excluded from further analyses.

Estimating bird densities. I used Program DISTANCE 7.3 (Thomas et al. 2010) to estimate population densities (birds/ha) corrected for imperfect detectability for each species breeding in Cork City. I conducted analyses separately for species with $>60$ detections (as per Buckland et al. 2001) across the 4-year period. Species with fewer than 60 detections were pooled together and 'species' was used as a covariate for evaluating variable detectabilities by species. I tested the fit of half-normal and hazard-rate detection functions with and without cosine and negative exponential series expansions in addition to survey-specific covariates. I 
obtained density estimates from the top-fitting detectability model. Then I used the package 'Ime4' (Bates et al. 2020) in R 3.6.2 (R Core Team 2019) to evaluate a set of nine linear mixed effects models incorporating urban habitat variables on species-specific density estimates. These models included solitary effects from each habitat variable, effects from the combinations of variables from the PCA, a global model (incorporating all variables), and a null model (suggesting none of the variables affected bird densities).

Estimating species richness. Species have varying levels of detectability (e.g., some species may be more difficult to detect than others) and thus raw species counts can be misleading. Therefore, I used Program SPECRICH2 to compute avian species richness for each survey point during the 4-year period of this study (White et al. 1978; Rexstad and Burnham 1991). SPECRICH2 uses a mark-recapture approach whereby presence-absence encounter histories are used to estimate species richness $(\hat{S})$ corrected for heterogeneous detection probabilities across species. Then, as with the bird density models described above, I used the package 'Ime4' (Bates et al. 2020) in R 3.6.2 (R Core Team 2019) to assess the fit of nine linear mixed effects models that evaluated effects from habitat variables on estimated species richness. The nine candidate models included effects from each variable alone, effects from variables combined as a result of the PCA, a global model, and a null model (indicating effects from none of the habitat variables.

Evaluating species composition. I used two approaches to characterize patterns in species composition across the city: (1) non-metric multidimensional scaling (NMDS) to evaluate species composition among the 32 survey points and three habitat categories, and (2) program COMDYN to estimate gamma diversity as a measure of species overlap among the three habitat categories. I used the package 'vegan' (Oksanen et al. 2020) in program R 3.6.2 (R 
Core Team 2019) to conduct the NMDS analysis - a distance-based ordination technique based on dissimilarities in rank-ordered relative abundances for each species (Bradfield and Kenkel 1987). In this NMDS analysis, I used Bray-Curtis (1957) distances which measures dissimilarities based on count information. This approach outperforms newer more data-hungry model-based methods for analyzing species composition data (Roberts 2020). Using NMDS to evaluate differences in species composition among points assumes that relative abundance supplies a measure of association or disassociation (i.e., number of detections supplies a measure of the degree of habitat association).

In conjunction with the NMDS analysis, I used Program COMDYN to estimate measures of species overlap among commercial, residential, and managed habitats. I used this approach because COMDYN incorporates estimates based on heterogeneous detection probabilities by species by utilizing a mark-recapture analysis framework (Hines et al. 1999; Nichols et al. 1998).

Model ranking. I used an information theoretic framework (Burnham and Anderson 2002) to rank candidate sets of models evaluating effects of habitat variables on (1) bird densities and (2) bird species richness. I ranked candidate density and species richness models using Akaike's information criterion corrected for small sample size $\left(\mathrm{AIC}_{c}\right)$. As per Burnham and Anderson 2002, models with $\triangle A I C_{c}$ values $<2.0$ were considered most plausible given the data. Models with $\triangle A I C_{c}$ values $>8.0$ were considered least plausible. I model-averaged parameter estimates using $A I C_{c}$ weights to evaluate the magnitude of effects from each habitat variable on species richness.

Comparing between estimates. Density and species richness estimates were compared by examining the magnitude of confidence intervals around differences between estimates. For 
computing confidence intervals around differences, I calculated the variance of each difference as:

$$
\operatorname{Var}\left(\widehat{S_{1}}-\widehat{S_{2}}\right)=\operatorname{Var}\left(\widehat{S_{1}}\right)+\operatorname{Var}\left(\widehat{S_{2}}\right)-2 * \operatorname{Cov}\left(\widehat{S_{1}}, \widehat{S_{2}}\right)
$$

The magnitude of differences was considered strong when $95 \%$ confidence intervals were greater than 0.0 , moderate when $90 \%$ CIs were greater than 0.0 , weak when $85 \%$ CIs did not include 0.0, and no difference when 85\% CIs included zero (Gerard et al. 1999; Skagen et al. 2005).

\section{RESULTS}

A total of 45 species were detected during the breeding seasons of 2016-2019 throughout Cork City (Table 2). Overall I detected more species on average (SE) in managed habitats versus either residential or commercial - 22.8 (1.2), 16.5 (1.7), and 11.7 (0.9) detected species, respectively. Twenty-two species were detected in all three habitat categories. The most commonly detected species throughout the city were Eurasian Jackdaw, Rook, and European Starling. Nine species were only detected in managed habitats: Mallard, Eurasian Moorhen, Little Egret, Eurasian Jay, Coal Tit, Eurasian Blackcap, Mistle Thrush, Sand Martin, and Willow Warbler. No species were detected exclusively in either residential or commercial habitats. European Greenfinch was only detected during 2016 and not during the other three years of the study. Species known to occur in Cork City but not detected during bird surveys included Little Grebe (Tachybaptus ruficollis), Stock Dove (Columba oenas), European Kingfisher (Alcedo atthis), and White-throated Dipper (Cinclus cinclus) (Mundy 2014; eBird 2020; Irish Birding 2020; personal observations). 


\section{Principal Components Analysis}

The PCA revealed two dimensions that described $75.2 \%$ of the variation in the data (Figure 2).

Dimension one included effects from distance to the periphery, distance to the core, amount of gray space, and urban noise levels at each point. Dimension two included strong effects from both income and distance to nearest wooded habitat. These seven variables were used in models evaluating effects on population densities and species richness. Both distance to water and vegetational cover contributed more to dimension 3 and thus neither varied substantially across survey points, resulting in minimal influence from these variables on the PCA. These two variables were excluded from the density and species richness models.

\section{Bird densities}

Density estimates ranged from only $0.01 \mathrm{birds} /$ ha for both Little Egrets and Sand Martins (the two least abundant species) to 7.02 birds/ha for Rock Pigeons (the most abundant species; Table 2). Nine species had $>60$ detections across the 4-year period of this study and thus these were the species for which I estimated habitat-specific densities (Table 3) and analyzed effects from urban variables. Seven of these nine species had higher densities in managed habitats compared with either residential or commercial (Table 4). There were at least 0.8 more House Sparrows/ha in residential areas versus managed green spaces (i.e., 74\% more Houses Sparrows in residential areas compared with managed habitats). The Rook was the only species with higher densities in commercial regions. Eurasian Blackbird densities were higher in both managed and residential habitats compared with commercial. The biggest differences in estimated densities were between managed versus commercial regions for both Eurasian Blackbirds and Common WoodPigeons (both had $>2.5$ more birds/ha in managed habitats). 
The amount of gray space appeared in top models for six of the nine species (Table 5). Model-averaged regression coefficients revealed that the amount of gray space had the greatest effect on densities of four of the nine species analyzed (Table 6). Densities of Common WoodPigeons, Eurasian Wrens, and Eurasian Blackbirds were negatively related to the amount of gray space; however, Rock Pigeon densities were positively related to this variable.

The distance to urban core appeared in top models for five species. However, effects from the distance to urban core on bird densities was trivial (i.e., 95\% CI's were very near zero) or inconclusive (i.e., 95\% CI's included both biologically meaningful and trivial levels) for all nine species. Income did not affect the density of any of the nine species (i.e., the magnitudes of the $95 \%$ CIs were very low and included zero).

Eurasian Wren densities also showed negative relationships with distance to nearest wooded area and average urban noise levels (however, the effect from noise pollution on wren densities may be biologically trivial given that the $95 \%$ CI for this beta is very close to zero). House Sparrow densities increased with increasing distance to wooded areas. The null model was top-ranked for Rook and European Starling, suggesting that densities for these two species may have been relatively ubiquitous across all combinations of habitat variables.

\section{Bird species richness}

Estimated avian species richness $(95 \% \mathrm{CI})$ was $26.2(17.9,34.4)$ species in managed habitats, $20.1(13.7,26.5)$ species in residential habitats, and $15.1(9.4,20.8)$ species in commercial habitats. There was a strong difference (i.e., $95 \%$ CI was greater than zero) of $11.1(1.0,21.1)$ species between managed versus commercial habitats, suggesting there was at least 1.0 (but possibly 21.1) more species in managed versus commercial habitats. There was no difference 
(i.e., 85\% CIs included zero) in estimated species richness between managed versus residential $(6.1[-1.7,13.9]$ species $)$ or residential versus commercial $(5.0[-1.4,11.4]$ species $)$ habitats.

The single top-ranked species richness model included the effects from dimension 1 in the PCA: distance to the urban periphery, distance to the urban core, noise levels, and amount of gray space (Table 7). This model had $79 \%$ of the weight from the data. No other model was considered plausible (i.e., all other models had $\Delta \mathrm{AIC}_{c}>4.0$ ). Additionally, models that excluded amount of gray space were $>300$ times less plausible than the models that did. The modelaveraged regression coefficients (SEs) for these variables suggested negative effects on species richness from distance to urban periphery $\left(\beta_{\text {DistPeriph }}=-2.16[1.39]\right)$, noise levels $\left(\beta_{\text {AvedB }}=\right.$ $-0.37[0.18])$, and gray space $\left(\beta_{\text {Grayspace }}=-5.68[3.74]\right)$, and positive effects from distance to core $\left(\beta_{\text {DistCore }}=2.35\right.$ [1.41]). However, the high level of error in these estimates suggests weak support for the strength of the magnitude of these effects.

Species richness decreased with increasing distance to urban periphery, noise levels, gray space, and distance from wooded areas (Figure 3). Species richness increased with distance from the urban core and may increase with increasing median household incomes; however there appears to be high variation in species richness in regions with high income levels and thus this variable is inconclusive due to imprecision (coincident with model selection results that indicate little evidence that this variable affected species richness).

\section{Bird species composition}

The NMDS analysis revealed substantial species overlap among the three habitat categories (Figure 4); however, more species showed a stronger association with managed habitats than either residential or commercial habitats. No species showed strong association with commercial 
habitats. Estimated gamma diversity levels $(95 \% \mathrm{CI})$ indicated substantial overlap in species composition across the habitats: $0.95(0.80,1.00)$ for managed versus commercial, $0.94(0.75$, 1.00) for managed versus residential, and $0.88(0.63,1.00)$ for residential versus commercial. Note that all gamma diversity estimates have $95 \%$ Cl's that include $100 \%$ overlap.

\section{DISCUSSION}

Bird species in Ireland are at the western periphery of their global distributions and most of these populations are isolated from those in Great Britain or mainland Europe. It is important to understand the effects of urbanization on these island isolated bird communities in order to inform future urban planning as Cork City continues to grow rapidly.

\section{The importance of managed green spaces for the birds of Cork City}

It is not surprising that bird densities and species richness were positively related to urban green space in Cork City. Managed green spaces elsewhere typically have higher vegetation structural diversity (e.g., shrubs, hedgerows, trees, etc.), supplying increased cover for nesting and availability of food (e.g., arthropods and fruits) (Donnelly and Marzluff 2004). Several other studies have reported similarly positive effects on biodiversity from vegetation structural diversity in urban landscapes (Ferenc et al. 2014; MacGregor-Fors et al. 2016; Threlfall et al. 2017). The results from this study add to the body of literature supporting the importance of city green spaces for maintaining urban biodiversity.

Both Eurasian Blackbirds and Common Wood-Pigeons had substantially higher estimated densities in the urban green spaces compared with residential and commercial habitats. Eurasian Blackbirds are known to be common throughout city centers across Europe with higher 
densities in regions near green spaces with open grass for foraging (Collar and Christie 2020). Common Wood-Pigeons are recently considered urban specialists throughout Europe, foraging and nesting in city parks and on buildings (Baptista et al. 2020). However, Common WoodPigeons have been known to prefer green spaces for foraging which supports the negative relationship I found with amount of gray space (Baptista et al. 2020).

The Eurasian Wren is considered the most abundant bird in Ireland (Crowe et al. 2014). While wrens are habitat generalists and thus maintain distributions in cities, urban distributions are generally associated with highly vegetated areas (Kroodsma et al. 2020). This may explain the negative relationship I found with distance to wooded vegetation in Cork City. The negative relationship between Eurasian Wren densities and urban noise pollution may be because birds may vocalize less frequently in a noisy environment or may be more difficult to detect.

The distance to water variable did not contribute much to the variation in these data likely because most locations throughout Cork City were within 200 m of water (e.g., the River Lee running through the middle of the city).

\section{The role of commercial and residential habitats for birds in Cork City}

Only a few species had higher densities and/or associations with commercial or residential habitats compared with green spaces. Rooks are known to be associated with large city parks throughout Europe (Madge 2020); however, I found higher densities in commercial regions of Cork City. This is likely because they are opportunistic generalists (i.e., scavengers) that have benefited from anthropogenic activities (Kark et al. 2007; Madge 2020). House Sparrows had higher densities in residential habitats because their breeding ecology includes nesting on houses (Lowther and Cink 2020). Both House Sparrows and Rock Pigeons are generally associated 
with human modified habitats all around the globe, and thus populations of these species tend to increase or remain stable in urban locations (Lowther and Cink 2020; Lowther and Johnston 2020).

The urban habitat variable that had the broadest negative effect on densities and species richness was the amount of gray space. Regions with high coverage of gray space consequently have reduced vegetational coverage and thus a reduction in breeding habitat for most species. Rock Pigeons directly utilize gray spaces for nesting (Lowther and Johnston 2020), explaining why this was the only species with densities that were positively correlated (albeit weakly so) to the amount of gray space.

In addition to gray space, estimated densities and species richness were negatively affected by distance to the urban periphery, proximity to woody habitat patches, and noise pollution levels at each point. These results corroborate many other studies having shown similar effects in other cities throughout the world (Dale 2018, Francis et al. 2009, Ortega 2012). There are several potential reasons why densities and richness estimates were negatively related to increased distance to the urban periphery and positively related to distance to the urban core. Species that were detected closer to the urban periphery and farther from the city center may be more neophobic and thus less tolerant of increased human activity. An alternative explanation may be that these species are in competition with the species that are concentrated in the urban center. Many species that thrive in urban environments have broad niches and thus are strong competitors to species less tolerant of urbanization (Bonier et al. 2007; Jokimäki et al. 2016).

Socioeconomic factors such as neighborhood median household income levels have been shown in other studies to affect bird populations and distributions (Strohbach et al. 2009). My results suggest that variable income levels had minimal effect on birds in Cork City during this 
4-year study. This may change as Cork City continues to grow as a global economic hub.

Future research should continue to monitor this variable as well as neighborhood age as this has been shown to be an important variable in other cities (Loss et al. 2009).

\section{Conservation implications.}

As Cork City continues to grow both geographically and economically, management should focus on adding additional green spaces and improving the existing locations. This is particularly important for these populations that are isolated and at the western periphery of their global distributions. Certainly, adding new green spaces may be difficult given the extent to which current urban land uses are established; however, as the city expands geographically, planners could prioritize the development and protection of new green spaces. Additionally, existing green spaces of marginal quality could be enhanced by increasing vegetational heterogeneity of native plants. Ultimately, green spaces in Cork City should be designated as important bird areas (by conservation groups like BirdLife International and BirdWatch Ireland) to provide support for conservation to maintain urban biodiversity in this core on the Atlantic margin of Europe.

\section{ACKNOWLEDGMENTS}

I thank Dr. Tom Kelly with the University College Cork (UCC) for consultations during the survey design stage of this study as well as for reviewing earlier drafts of this paper. I also thank Dr. John Quinn and the School of Biological, Earth and Environmental Sciences at UCC for providing useful advice along the way as well as office space and library access. I thank the following Le Moyne College programs for funding this project: O’Leary International Travel 
Grants Program, Research and Development Committee, and the Center for Urban and Regional Applied Research. 


\section{Declarations}

Funding: Funding was supplied by the following Le Moyne College grant programs: O’Leary International Travel Grants Program, Research and Development Committee, and the Center for Urban and Regional Applied Research. No external funding was used on this project.

Conflicts of interest/Competing interests: There were no conflicts of interest or competing interests associated with this study.

Ethics approval: Not applicable.

Consent to participate: Not applicable.

Consent for publication: Not applicable.

Availability of data and material: Data will be made available via an online data repository upon request and/or acceptance for publication.

Code availability: Not applicable.

Authors' contributions: The entirety of this project was completed by a single author. 


\section{Literature cited}

Adams CE, Lindsey KJ, Ash SJ (2006) Urban Wildlife Management. Taylor and Francis Group, Boca Raton, Florida, USA.

Andersson E, Barthel S, Borgström S, Colding J, Elmqvist T, Folke C, Gren Å (2014)

Reconnecting cities to the biosphere: stewardship of green infrastructure and urban ecosystem services. AMBIO 43:445-453.

Baptista LF, Trail PW, Horblit HM, Boesman PFD, Garcia EFJ (2020) Common Wood-Pigeon (Columba palumbus), version 1.0. In Birds of the World (J. del Hoyo, A. Elliott, J. Sargatal, D.A. Christie, and E. de Juana, Editors). Cornell Lab of Ornithology, Ithaca, New York, USA.

Bates D, Maechler M, Bolker B, Walker S, Christensen RHB, Singmann H, Dai B, Scheipl F, Grothendieck G, Green P, Fox J, Bauer A, Krivitsky PN (2020) Package 'Ime4:' Linear mixedeffects models using ‘Eigen’ and S4. R package version 1.1-26.

Beninde J, Veith M, Hochkirch A (2015) Biodiversity in cities needs space: a meta-analysis of factors determining intra-urban biodiversity variation. Ecology Letters 18(6):581-592.

Billerman SM, Keeney BK, Rodewald PG, Schulenberg TS (2020) Birds of the World. Cornell Laboratory of Ornithology, Ithaca, New York, USA. 
Biodiversity Information System for Europe. 2020.

https://biodiversity.europa.eu/countries/ireland (Accessed: 7 April 2020).

Biroli AP, Van Doren BM, Grabowska-Zhang A (2020) Drivers of avian species richness and community structure in urban courtyard gardens. Journal of Urban Ecology 6(1):1-11.

Bonier F, Martin PR, Wingfield JC (2007) Urban birds have broader environmental tolerance. Biology Letters 3(6):670-673.

Bradfield GE, Kenkel NC (1987) Nonlinear ordination using flexible shortest path adjustment of ecological distances. Ecology 68(3):750-753.

Bray JR, Curtis JT (1957) An ordination of upland forest communities of southern Wisconsin. Ecological Monographs 27:325-349.

Buckland ST, Anderson DR, Burnham KP, Laake JL, Borchers DL, Thomas L (2001) Introduction to distance sampling: estimating abundance of biological populations. Oxford University Press, New York, USA.

Burnham KP, Anderson DR (2002) Model selection and multimodel inference: a practical information-theoretic approach. Springer-Verlag, New York, New York, USA.

Central Statistics Office (2016a) Geographical profiles of income in Ireland 2016. 
Central Statistics Office (2016b) Population and Actual and Percentage Change 2011 to 2016 by Aggregate Town or Rural Area, County and City, Sex, Statistical Indicator and Census Year.

Collar N, Christie DA (2020). Eurasian Blackbird (Turdus merula), version 1.0. In Birds of the World (J. del Hoyo, A. Elliott, J. Sargatal, D.A. Christie, and E. de Juana, Editors). Cornell Lab of Ornithology, Ithaca, New York, USA.

Cork City Council (2019) Boundary extension. https://www.corkcity.ie/en/councilservices/public-info/boundary-extension/

Crowe O, Coombes RH, Lysaght L, O'Brien C, Choudry KR, Walsh AJ, Wilson JH, O'Halloran J (2010) Population trends of widespread breeding birds in the Republic of Ireland 1998-2008. Bird Study 57(3):267-280.

Crowe O, Musgrave AJ, O’Halloran J (2014) Generating population estimates for common and widespread breeding birds in Ireland. Bird Study 61: 82-90.

Dale S (2018) Urban bird community composition influenced by size or urban green spaces, presence of native forest, and urbanization. Urban Ecosystems 21:1-14. 
Department of Agriculture, Food, and the Marine (2020) Forest Statistics Ireland 2020.

Department of Agriculture, Food, and the Marine, County Wexford, Ireland.

https://www.agriculture.gov.ie/forestservice (Accessed 15 January 2021).

Department of Housing, Planning and Local Government (2017) Project Ireland 2040: National Planning Framework. Government of Ireland.

Department of Housing, Local Government and Heritage (2020) Generalized Zoning Types: GIS Data for Ireland. Government of Ireland. https://myplan.ie/zoning-map-viewer/ (Accessed 28 January 2020).

Donnelly R, Marzluff JM (2004) Importance of reserve size and landscape context to urban bird conservation. Conservation Biology 18:733-745.

Dow K (2000) Social dimensions of gradients in urban ecosystems. Urban Ecosystems 4:255275.

Duhl T, Guenther AB, Helmig D (2012) Estimating urban vegetation cover fraction using Google Earth ${ }^{\circledR}$ images. Journal of Land Use Science 7(3):311-329.

eBird (2020) eBird: An online database of bird distribution and abundance. eBird, Cornell Lab of Ornithology, Ithaca, New York, USA. Available: http://www.ebird.org. (Accessed: 15 January 2020). 
Ferenc M, Sedláček O, Fuchs R (2014) How to improve urban greenspace for woodland birds: site and local-scale determinants of bird species richness. Urban Ecosystems 17:625-640.

Fernández-Juricic E (2000). Avifaunal use of wooded streets in an urban landscape. Conservation Biology 14(2):513-521.

Fernández-Juricic E, Jokimäki J (2001) A habitat island approach to conserving birds in urban landscapes: case studies from southern and northern Europe. Biodiversity and Conservation 10:2023-2043.

Francis CD, Ortega CP, Cruz A (2009) Noise pollution changes avian communities and species interactions. Current Biology 19(16):1415-1419.

Fuller RJ, Gaston KJ, Quine CP (2007) Living on the edge: British and Irish woodland birds in a European context. Ibis 149:53-63.

Gerard PD, Smith DR, Weerakkody G (1998) Limits of retrospective power analysis. Journal of Wildlife Management 62: 801-807.

Hines JE, Boulinier T, Nichols JD, Sauer JR, Pollock KH (1999) COMDYN: software to study the dynamics of animal communities using a capture-recapture approach. Bird Study 46(suppl.): S209-217. 
Hope D, Gries C, Zhu W, Fagan WF, Redman CL, Grimm NB, Nelson AL, Martin C, Kinzig A (2003) Socioeconomics drive urban plant diversity. Proceedings of the National Academy of Science 100(15):8788-8792.

Irish Birding (2020) Irish Birding: Sightings. http://www.irishbirding.com. (Accessed: 15 January 2020).

James FC, McCulloch CE (1990) Multivariate analysis in ecology and systematics: panacea or Pandora's Box? Annual Review of Ecology and Systematics 21:129-166.

Jokimäki J, Kaisanlahta-Jokimäki ML, Carbó-Ramírez P (2014) Chapter 16: The importance of wooded urban green areas for breeding birds: a case study from Northern Finland. Avian Urban Ecology: Behavioural and Physiological Adaptations. Eds. Gil and Brumm. Oxford University Press. United Kingdom.

Jokimäki J, Suhonen J, Jokimäki-Kaisanlahti ML, Carbó-Ramírez P (2016) Effects of urbanization on breeding birds in European towns: impacts of species traits. Urban Ecosystems $19: 1565-1577$.

Kark S, Iwaniuk A, Schalimtzek A, Banker E (2007) Living in the city: can anyone become an 'urban exploiter'? Journal of Biogeography 34(4):638-651. 
Kassambara A, Mundt F (2020) Package 'factoextra:' extract and visualize the results of multivariate data analyses. R package version 1.0.7.

Kinzig AP, Warren P, Martin C, Hope D, Katti M (2005) The effects of human socioeconomic status and cultural characteristics on urban patterns of biodiversity. Ecology and Society 10(1):23.

Korányi D, Gallé R, Donkó B, Chamerlain DE, Batáry P (2020) Urbanization does not affect green space bird species richness in a mid-sized city. Urban Ecosystems online.

Kroodsma DE, Brewer D, Christie DA, Marks JS (2020) Eurasian Wren (Troglodytes troglodytes), version 1.0. In Birds of the World (J. del Hoyo, A. Elliott, J. Sargatal, D.A. Christie, and E. de Juana, Editors). Cornell Lab of Ornithology, Ithaca, New York, USA.

Lewis L, Coombes D, Burke B, O’Halloran J, Walsh A, Tierney D, Cummins S (2019) Countryside Bird Survey: Status and trends of common and widespread breeding birds 19982016. Irish Wildlife Mannuals, No. 115. National Parks and Wildlife Service, Department of Culture, Heritage and the Gaeltacht, Ireland.

Loss SR, Ruiz MO, Brawn JD (2009) Relationships between avian diversity, neighborhood age, income, and environmental characteristics of an urban landscape. Biological Conservation 142:2578-2585. 
Lowther PE, Cink CL (2020) House Sparrow (Passerus domesticus), version 1.0. In Birds of the World (S.M. Billerman, Editor). Cornell Lab of Ornithology, Ithaca, New York, USA.

Lowther PE, Johnston RF (2020) Rock Pigeon (Columba livia), version 1.0. In Birds of the World (S.M. Billerman, Editor). Cornell Lab of Ornithology, Ithaca, New York, USA.

MacGregor-Fors I, Escobar F, Rueda-Hernández R, Avendaño-Reyes S, Baena ML, Bandala VM, Chacón-Zapata S, Guillén-Servent A, González-García F, Lorea-Hernández F, Montes de Oca E, Montoya L, Pineda E, Ramírez-Restrepo L, Rivera-García E, Utrera-Barrillas E (2016) City "green" contributions: the role of urban greenspaces as reservoirs for biodiversity. Forests $7: 1-14$

Madge S (2020) Rook (Corvus frugilegus), version 1.0. In Birds of the World (J. del Hoyo, A. Elliott, J. Sargatal, D.A. Christie, and E. de Juana, Editors). Cornell Lab of Ornithology, Ithaca, New York, USA.

Martin TE, Paine C, Conway CJ, Hochachka WM, Allen P, Jenkins W (1997) BBIRD field protocol. Montana Cooperative Wildlife Research Unit, University of Montana, Missoula, MT, USA.

Marzluff JM (2001) Worldwide urbanization and its effects on birds. In: Marzluff, J.M., R. Bowman, and R. Donnelly (eds), Avian Ecology and Conservation in an Urbanizing World. Springer, Boston, Massachusetts, USA. 
Melles SJ (2005) Urban bird diversity as an indicator of human social diversity and economic inequality in Vancouver, British Columbia. Urban Habitats 3(1):25-48.

Mundy R (2014) Nature in the city: a guide to biodiversity in Cork City. Cork City Council, Cork City, County Cork, Ireland.

National Biodiversity Data Centre (2020) National Biodiversity Data Center: Documenting Ireland's Wildlife. Department of Culture, Heritage and the Gaeltacht. https://www.biodiversityireland.ie (Accessed: 7 April 2020).

Nichols JD, Boulinier T, Hines JE, Pollock KH, Sauer JR (1998) Estimating rates of local species extinction, colonization, and turnover in animal communities. Ecological Applications 8:1213-1225.

Nilon CH, Aronson MFJ, Cilliers SS, Dobbs C, Frazee LJ, Goddard MA, O’Neill KM, Roberts D, Stander EK, Werner P, Winter M, Yocom KP (2017) Planning for the future of urban biodiversity: a global review of city-scale initiatives. BioScience 67(4):332-342.

Oksanen J, Blanchet FG, Friendly M, Kindt R, Legendre P, McGlinn D, Minchin PR, O’Hara RB, Simpson GL, Solymos P, Henry M, Stevens H, Szoecs E, Wagner H (2020) Vegan: community ecology package. R package version 2.5-7. 
Ortega CP (2012) Chapter 2: Effects of noise pollution on birds: a brief review of our knowledge. Ornithological Monographs 2012(74):6-22.

Pickett STA, Burch Jr. WR, Dalton SE, Foresman TW, Grove JM, Rowntree R (1997) A conceptual framework for the study of human ecosystems in urban areas. Urban Ecosystems 1:185-199.

Preininger D, Schoas B, Kramer D, Boeckle M (2019) Waste disposal sites as all-you-can eat buffets for Carrion Crows (Corvus corone). Animals 9:1-15.

R Core Team (2019) R: A language and environment for statistical computing. R Foundation for Statistical Computing, Vienna, Austria. URL https://www.R-project.org/.

Rebele F (1994) Urban ecology and special features of urban ecosystems. Global Ecology and Biogeography Letters 4:173-187.

Reijnen R, Foppen R, Braak CT, Thissen J (1995) The effects of car traffic on breeding bird populations in woodland. III. Reduction of density in relation to the proximity of main roads. Journal of Applied Ecology 32:187-202.

Rexstad E, Burnham KP (1991) User's Guide for Interactive Program CAPTURE. Colorado Cooperative Fish and Wildlife Research Unit, Colorado State University, Fort Collins, Colorado, USA. 
Roberts DW (2020) Comparison of distance-based and model-based ordinations. Ecology 101(1):1-12.

Samia DSM, Blumstein DT, Diaz M, Grim T, Ibáñez-Álamo JD, Jokimäki J, Tätte K, Markó G, Tryjanowski P, Møller AP (2017) Rural-urban differences in escape behavior of European birds across a latitudinal gradient. Frontiers in Ecology and Evolution 5:66.

Skagen SK, Kelly JF, van Riper III C, Hutto RL, Finch DM, Krueper DJ, Melcher CP (2005)

Geography of spring landbird migration through riparian habitats in southwestern North America. Condor 107:212-227.

Soanes K, Lentini PE (2019) When cities are the last chance for saving species. Frontiers in Ecology and the Environment 17(4): 225-231.

Strohbach MW, Hasse D, Kabisch N (2009) Birds and the city: urban biodiversity, land use, and socioeconomics. Ecology and Society 14(2):31.

Thomas L, Buckland ST, Rexstad EA, Laake JL, Strindberg S, Hedley SL, Bishop JRB, Marques TA, Burnham KP (2010) Distance software: design and analysis of distance sampling surveys for estimating population size. Journal of Applied Ecology 47:5-14. 
Threlfall CG, Mata L, Mackie JA, Hahs AK, Stork NE, Williams NSG, Livesley SJ (2017) Increasing biodiversity in urban green spaces through simple vegetation interventions. Journal of Applied Ecology 54:1874-1883.

Tilghman NG (1987) Characteristics of urban woodlands affecting breeding bird diversity and abundance. Landscape and Urban Planning 14:481-495.

United Nations (2015) Transforming our world: the 2030 agenda for sustainable development. New York: UN Publishing. Website:

https://sustainabledevelopment.un.org/post2015/transformingourworld

United Nations (2018) 2018 Revision of the World Urbanization Prospects. Population Division of the United Nations Department of Economic and Social Affairs. Website: https://www.un.org/development/desa/publications/2018-revision-of-world-urbanizationprospects.html

Vuorisalo T, Andersson H, Hugg T, Lahtinen R, Laaksonen H, Lehikoinen E (2003) Urban development from an avian perspective: causes of Hooded Crow (Corvus corone cornix) urbanization in two Finnish cities. Landscape and Urban Planning 62(2)69-87.

White GC, Burnham KP, Otis DL, Anderson DR (1978) User's Manual for Program CAPTURE. Utah State University Press, Logan, Utah, USA. 
Withey JC, Marzluff JM (2008) Multi-scale use of lands providing anthropogenic resources by American Crows in an urbanizing landscape. Landscape Ecology 24: 281. 
Table 1. Urban habitat variables measured at each site; these mnemonics were used in model notation for evaluating patterns in both bird densities and species richness. Citations lend support for including variables in candidate models for explaining bird population densities and species richness.

\begin{tabular}{|c|c|c|}
\hline Mnemonic & Variable & Description and methods \\
\hline Habitat & Urban habitat type & $\begin{array}{l}\text { This is a categorical variable representing the } \\
\text { habitat type at each survey point: managed, } \\
\text { residential, or commercial (as defined by } \\
\text { Adams et al. } 2006 \text {; Beninde et al. } 2015 \text { ) }\end{array}$ \\
\hline DistWood & $\begin{array}{l}\text { Distance }(\mathrm{km}) \text { to nearest } \\
\text { vegetation cover }>1 \text { ha }\end{array}$ & $\begin{array}{l}\text { Measured the distance to the nearest wooded } \\
\text { habitat patch } \geq 1 \text { ha in size (Tilghman } 1987 \text {, } \\
\text { Fernández-Juricic 2000, Fernández-Juricic and } \\
\text { Jokimäki 2001, Jokimäki et al. 2014). }\end{array}$ \\
\hline AvedB & Average sound (dB) & $\begin{array}{l}\text { Recorded with a sound meter during each 10- } \\
\text { min survey period (Reijnen et al. 1995, Francis } \\
\text { et al. } 2009 \text {, Ortega 2012). }\end{array}$ \\
\hline DistWater & $\begin{array}{l}\text { Distance }(\mathrm{km}) \text { to nearest } \\
\text { water }\end{array}$ & $\begin{array}{l}\text { Measured using ArcGIS; water was defined as } \\
\text { any permanent water source such as streams, }\end{array}$ \\
\hline
\end{tabular}


DistCore Distance $(\mathrm{km})$ to urban core Measured using ArcGIS; urban core was defined as the middle of the commercial city center (i.e., not the city's geographical center; Jokimäki et al. 2014).

DistPeriph Distance (km) to urban periphery

Income

Vegetation
Average household income

$(€)$
Measured using ArcGIS; urban periphery was defined as the edge of continuous gray space at the periphery of the city (i.e., often extending beyond the political boundary of the city; Fernández-Juricic and Jokimäki 2001, Dale 2018).

Data from Central Statistics Office 2016a (Dow 2000, Kinzig et al. 2005, Melles 2005, Strohbach et al. 2009).

Estimated percent woody vegetational cover (e.g., trees and shrubs) within a 100-m radius of each survey point using the most recent Google Earth® images (Duhl et al. 2012, Beninde et al. 2015, Dale 2018). 
GraySpace Amount of gray space (\%) Estimated percent of gray space within a 100-m radius of each survey point; the direct inverse of this would be percent of green space (different from Vegetation in that this would include mowed lawns, green roofs, etc.). 
Table 2. Estimated breeding bird densities (birds/ha) and abundances for Cork City during 2016-2019.

Estimated $95 \%$ confidence intervals are included in parentheses.

\begin{tabular}{|c|c|c|c|c|}
\hline \multirow{2}{*}{$\begin{array}{l}\text { Species name } \\
\text { Cygnus olor }\end{array}$} & \multirow{2}{*}{$\begin{array}{l}\text { Common name } \\
\text { Mute Swan }\end{array}$} & Birds/ha & \multicolumn{2}{|c|}{ Total no. } \\
\hline & & $0.04 \quad(0.01,0.24)$ & 157 & $(26,951)$ \\
\hline Anas platyrhynchos & Mallard & $0.33 \quad(0.13,0.79)$ & 1296 & $(534,3145)$ \\
\hline Columba livia & Rock Pigeon & $7.02 \quad(5.42,9.08)$ & 27779 & $(21451,35973)$ \\
\hline C. palumbus & Common Wood-Pigeon & $2.78 \quad(2.36,3.28)$ & 11025 & $(9354,12993)$ \\
\hline Streptopelia decaocto & Eurasian Collared-Dove & $0.17 \quad(0.09,0.33)$ & 668 & $(337,1323)$ \\
\hline Apus apus & Common Swift & $0.84 \quad(0.55,1.29)$ & 3338 & $(2175,5121)$ \\
\hline Gallinula chloropus & Eurasian Moorhen & $0.06 \quad(0.01,0.25)$ & 236 & $(56,986)$ \\
\hline \multirow[t]{2}{*}{ Larus argentatus } & Herring Gull & $0.35 \quad(0.18,0.66)$ & 1374 & $(724,2610)$ \\
\hline & Lesser Black-backed & & & \\
\hline \multirow[t]{2}{*}{ L. fuscus } & Gull & $0.07 \quad(0.03,0.16)$ & 275 & $(120,628)$ \\
\hline & Great Black-backed & & & \\
\hline L. marinus & Gull & $0.02 \quad(0.01,0.06)$ & 79 & $(24,253)$ \\
\hline
\end{tabular}




\begin{tabular}{|c|c|c|c|c|c|}
\hline Phalacrocorax carbo & Great Cormorant & 0.03 & $(0.01,0.11)$ & 118 & $(33,425)$ \\
\hline Ardea cinerea & Grey Heron & 0.12 & $(0.04,0.36)$ & 471 & $(158,1407)$ \\
\hline Egretta garzetta & Little Egret & 0.01 & $(0.01,0.05)$ & 39 & $(8,199)$ \\
\hline Garrulus glandarius & Eurasian Jay & 0.02 & $(0.01,0.10)$ & 79 & $(15,398)$ \\
\hline Pica pica & Eurasian Magpie & 0.70 & $(0.46,1.08)$ & 2788 & $(1812,4289)$ \\
\hline Corvus monedula & Eurasian Jackdaw & 3.31 & $(2.85,3.84)$ & 13112 & $(11302,15210)$ \\
\hline C. frugilegus & Rook & 5.37 & $(4.54,6.35)$ & 21257 & $(17970,25150)$ \\
\hline C. cornix & Hooded Crow & 0.40 & $(0.31,0.51)$ & 1572 & $(1224,2020)$ \\
\hline C. corax & Common Raven & 0.03 & $(0.01,0.11)$ & 118 & $(32,400)$ \\
\hline Periparus ater & Coal Tit & 0.07 & $(0.02,0.25)$ & 275 & $(77,987)$ \\
\hline Cyanistes caeruleus & Eurasian Blue Tit & 0.44 & $(0.25,0.75)$ & 1728 & $(1001,2982)$ \\
\hline Parus major & Great Tit & 0.23 & $(0.15,0.35)$ & 903 & $(590,1382)$ \\
\hline Phylloscopus collybita & Common Chiffchaff & 0.14 & $(0.06,0.31)$ & 550 & $(248,1217)$ \\
\hline Aegithalos caudatus & Long-tailed Tit & 0.09 & $(0.03,0.23)$ & 353 & $(137,911)$ \\
\hline Sylvia atricapilla & Eurasian Blackcap & 0.04 & $(0.01,0.11)$ & 157 & $(57,429)$ \\
\hline Regulus regulus & Goldcrest & 0.36 & $(0.21,0.59)$ & 1414 & $(850,2350)$ \\
\hline
\end{tabular}




\begin{tabular}{|c|c|c|c|c|c|}
\hline Certhia familiaris & Eurasian Treecreeper & 0.07 & $(0.03,0.15)$ & 275 & $(131,576)$ \\
\hline Troglodytes troglodytes & Eurasian Wren & 1.19 & $(0.82,1.73)$ & 4720 & $(3251,6851)$ \\
\hline Sturnus vulgaris & European Starling & 4.23 & $(3.38,5.28)$ & 16735 & $(13397,20905)$ \\
\hline Turdus viscivorus & Mistle Thrush & 0.03 & $(0.01,0.15)$ & 118 & $(23,598)$ \\
\hline T. philomelos & Song Thrush & 0.10 & $(0.05,0.20)$ & 393 & $(192,804)$ \\
\hline T. merula & Eurasian Blackbird & 2.95 & $(2.44,3.57)$ & 11682 & $(9647,14149)$ \\
\hline Erithacus rubecula & European Robin & 0.56 & $(0.33,0.93)$ & 2199 & $(1313,3683)$ \\
\hline Prunella modularis & Dunnock & 0.40 & $(0.27,0.59)$ & 1571 & $(1054,2341)$ \\
\hline Passer domesticus & House Sparrow & 3.49 & $(2.72,4.48)$ & 13820 & $(10775,17733)$ \\
\hline Motacilla cinerea & Grey Wagtail & 0.03 & $(0.01,0.11)$ & 118 & $(33,425)$ \\
\hline M. alba & White Wagtail & 0.31 & $(0.18,0.52)$ & 1217 & $(724,2047)$ \\
\hline Riparia riparia & Sand Martin & 0.01 & $(0.01,0.05)$ & 39 & $(8,199)$ \\
\hline Hirundo rustica & Barn Swallow & 0.19 & $(0.09,0.39)$ & 746 & $(356,1562)$ \\
\hline Delichon urbicum & Common House Martin & 0.41 & $(0.26,0.64)$ & 1610 & $(1015,2553)$ \\
\hline Phylloscopus trochilus & Willow Warbler & 0.07 & $(0.02,0.22)$ & 275 & $(88,863)$ \\
\hline Fringilla coelebs & Common Chaffinch & 0.74 & $(0.49,1.13)$ & 2945 & $(1933,4486)$ \\
\hline
\end{tabular}




\begin{tabular}{|c|c|c|c|c|}
\hline Pyrrhula pyrrhula & Eurasian Bullfinch & $0.15 \quad(0.05,0.46)$ & 589 & $(190,1827)$ \\
\hline Chloris chloris & European Greenfinch & $0.03 \quad(0.01,0.09)$ & 118 & $(39,360)$ \\
\hline Carduelis carduelis & European Goldfinch & $0.49 \quad(0.25,0.94)$ & 1924 & $(999,3707)$ \\
\hline
\end{tabular}


Table 3. Habitat specific density estimates (with $95 \%$ CIs) for the nine most commonly detected species of birds breeding in Cork City during 2016-2019.

\begin{tabular}{lcccccc}
\hline \multirow{2}{*}{ Species } & \multicolumn{7}{c}{ Birds/ha (95\% CI) } \\
\cline { 2 - 7 } & \multicolumn{2}{c}{ Managed } & \multicolumn{2}{c}{ Residential } & \multicolumn{2}{c}{ Commercial } \\
\hline Rock Pigeon & 7.1 & $(2.6,19.8)$ & 2.5 & $(1.3,5.9)$ & 8.2 & $(4.2,19.8)$ \\
Common Wood-Pigeon & 4.5 & $(3.4,5.9)$ & 2.3 & $(1.8,3.1)$ & 0.7 & $(0.5,3.3)$ \\
Eurasian Jackdaw & 3.0 & $(2.3,4.1)$ & 4.3 & $(3.2,6.0)$ & 2.6 & $(1.9,3.5)$ \\
Rook & 3.8 & $(2.8,5.1)$ & 2.6 & $(1.8,3.8)$ & 6.3 & $(4.6,8.6)$ \\
Hooded Crow & 0.6 & $(0.4,0.8)$ & 0.2 & $(0.2,0.3)$ & 0.3 & $(0.2,0.4)$ \\
Eurasian Wren & 1.3 & $(1.0,2.1)$ & 1.1 & $(0.7,1.6)$ & 0.5 & $(0.3,0.7)$ \\
European Starling & 5.3 & $(3.0,10.6)$ & 2.2 & $(1.3,3.8)$ & 1.3 & $(0.8,2.9)$ \\
European Blackbird & 4.2 & $(3.4,5.2)$ & 2.3 & $(1.8,3.0)$ & 0.7 & $(0.6,0.9)$ \\
House Sparrow & 1.1 & $(0.6,2.1)$ & 3.2 & $(2.1,6.7)$ & 1.9 & $(1.3,3.6)$ \\
\hline
\end{tabular}


Table 4. Differences between estimated breeding bird densities at managed, residential, and commercial habitats in Cork City during 2016-2019. Three levels of confidence intervals were computed to evaluate the magnitude of each difference - $85 \%$ (weak), $90 \%$ (moderate), and 95\% (strong). Bolded lower confidence limits (LCL) indicate the highest level of confidence for a difference.

\begin{tabular}{|c|c|c|c|c|c|c|c|c|}
\hline \multirow[b]{3}{*}{ Comparisons } & \multicolumn{7}{|c|}{ CIs for estimated differences (birds/ha) } & \multirow[b]{3}{*}{ Conclusion } \\
\hline & \multirow{2}{*}{$\begin{array}{c}\text { Est. } \\
\text { difference } \\
\text { (birds/ha) }\end{array}$} & \multicolumn{2}{|c|}{$85 \%$} & \multicolumn{2}{|c|}{$90 \%$} & \multicolumn{2}{|c|}{$95 \%$} & \\
\hline & & $\mathbf{L C L}$ & $\begin{array}{r}\mathbf{U C} \\
\mathbf{L}\end{array}$ & LCL & $\begin{array}{r}\mathbf{U C} \\
\mathbf{L}\end{array}$ & $\mathbf{L C L}$ & $\begin{array}{r}\mathbf{U C} \\
\mathbf{L}\end{array}$ & \\
\hline \multicolumn{9}{|l|}{ Rock Pigeon } \\
\hline Managed v. Residential & 4.6 & -0.6 & 9.9 & -1.3 & 10.5 & -2.4 & 11.7 & no difference \\
\hline Managed v. Commercial & 1.1 & -5.7 & 7.8 & -6.5 & 8.7 & -8.0 & 10.1 & no difference \\
\hline Residential v. Commercial & 5.7 & 1.2 & 10.2 & 0.6 & 10.8 & -0.3 & 11.8 & $\begin{array}{l}\text { moderate - at least } 0.6 \text { more Rock Pigeons/ha } \\
\text { in commercial }(90 \%)\end{array}$ \\
\hline
\end{tabular}

\section{Common Wood-Pigeon}


Managed v. Residential

Managed v. Commercial

Residential v. Commercial
Managed v. Residential

Managed v. Commercial

Residential v. Commercial

\section{Rook}

Managed v. Residential
1.6

1.3
0.22.

$$
0.0
$$$$
2.6
$$

$-0.2$ 2.8

$$
\text { managed }(85 \%)
$$

$\begin{array}{rrrr}-0.4 & 1.3 & -0.5 & 1.4 \\ 0.7 & 2.9 & 0.6 & 3 .\end{array}$

-0.6 1.6 no difference

$0.3 \quad 3.2$

strong - at least 0.3 more jackdaws/ha in residential (95\%)
0.12 .2
$2.3 \quad-0.3$
2.6 
Managed v. Commercial

Residential v. Commercial

$2.1 \quad 5$

5.2

$1.9 \quad 5.4$

1.6

commercial $(95 \%)$

strong - at least 1.6 more Rooks/ha in commercial $(95 \%)$

\section{Hooded Crow}

Managed v. Residential

$0.2 \quad 0.5$

0.5

0.2

0.5

0.1

0.6

. managed $(95 \%)$

Managed v. Commercial

$0.1 \quad 0.5$

0.1

0.5 strong - at least 0.1 more crows/ha in managed $(95 \%)$

Residential v. Commercial

$0.0 \quad 0.1$

0.0

0.1

0.0

0.2

no difference

\section{Eurasian Wren}

Managed v. Residential $\quad 0.2$

Managed v. Commercial

Residential v. Commercial

$\begin{array}{lllll}-0.2 & 0.7 & -0.3 & 0.8 & -0.4 \\ 0.5 & 1.2 & 0.4 & 1.3 & 0.8\end{array}$

$\begin{array}{llll}0.5 & 1.2 & 0.4 & 1.3\end{array}$

0.3 1.4 strong - at least 0.3 more Wrens/ha in

0.6

$\begin{array}{llll}0.3 & 0.9 & 0.3 & 1.0\end{array}$
managed (95\%) 


\section{European Starling}

Managed v. Residentia

3.1

0.9

5.3

$0.6 \quad 5.6$

0.1 6.1 strong - at least 0.1 more Starlings/ha in managed $(95 \%)$

Managed v. Commercial

1.8

6.1

$1.5 \quad 6$

Managed v. Commercial
Residential v. Commercial

\section{Eurasian Blackbird}

Managed v. Residential

1.0

2.7

0.8

82.9

$$
\text { managed (95\%) }
$$

Managed v. Commercial

$2.8 \quad 4$

4.1

$2.7 \quad 4.2$

2.5

2.54 .3

$$
\text { managed (95\%) }
$$

Residential v. Commercial

1.1

2.1

1.02
strong - at least 1.0 more blackbirds/ha in residential (95\%)

\section{House Sparrow}

Managed v. Residential
$\begin{array}{llll}1.1 & 3.1 & 1.0 & 3.2\end{array}$
0.8 3.4 strong - at least 0.8 more sparrows/ha in residential $(95 \%)$


Managed v. Commercial

0.8

Residential v. Commercial
1.3
$0.1 \quad 1.5$

$\mathbf{0 . 0} 1.60$

$60-0$

$0.2 \quad 2.4$ commercial $(85 \%)$

0.1 $2.5 \quad-0.2 \quad 2.7$ moderate - at least 0.1 more sparrows $/$ ha in residential $(90 \%)$ 
Table 5. Top-ranked models $\left(<2.0\right.$ delta $\left.A I C_{c}\left[\Delta_{i}\right]\right)$ for evaluating effects of urban habitat variables on breeding bird densities in Cork City during 2016-2019.

\begin{tabular}{|c|c|c|c|c|c|}
\hline \multirow[b]{2}{*}{ Species } & \multirow[b]{2}{*}{ Models } & \multicolumn{3}{|c|}{ No. of } & \multirow{2}{*}{$\begin{array}{c}\text { Akaike } \\
\text { weight }\left(w_{i}\right)\end{array}$} \\
\hline & & $\log (L)$ & parameters & $\Delta_{i}$ & \\
\hline \multirow[t]{4}{*}{ Rock Pigeon } & $\widehat{D}=$ DistPeriph + DistCore & -116.93 & 6 & 0.00 & 0.39 \\
\hline & $+A v e d B$ & & & & \\
\hline & + GraySpace & & & & \\
\hline & $\widehat{D}=$ DistCore & -121.27 & 3 & 0.16 & 0.36 \\
\hline \multirow[t]{4}{*}{ Common Wood-Pigeon } & $\widehat{D}=$ DistPeriph + DistCore & -52.74 & 6 & 0.00 & 0.66 \\
\hline & $+A v e d B$ & & & & \\
\hline & + GraySpace & & & & \\
\hline & $\widehat{D}=$ GraySpace & -57.69 & 3 & 1.40 & 0.37 \\
\hline Eurasian Jackdaw & $\widehat{D}=$ DistPeriph $*$ DistCore & -59.43 & 5 & 0.00 & 0.54 \\
\hline
\end{tabular}




\begin{tabular}{|c|c|c|c|c|c|}
\hline \multirow[t]{5}{*}{ Rook } & $\widehat{D}=$ GraySpace & -87.50 & 3 & 0.00 & 0.27 \\
\hline & $\widehat{D}=$ Intercept $($ null $)$ & .89 .22 & 2 & 1.00 & 0.16 \\
\hline & $\widehat{D}=$ Habitat & -86.87 & 4 & 1.36 & 0.14 \\
\hline & $\widehat{D}=A v e d B$ & -88.19 & 3 & 1.38 & 0.13 \\
\hline & $\widehat{D}=$ DistCore & -88.50 & 3 & 1.99 & 0.10 \\
\hline Hooded Crow & $\widehat{D}=$ DistPeriph $*$ DistCore & 4.04 & 5 & 0.00 & 0.78 \\
\hline \multirow[t]{2}{*}{ Eurasian Wren } & $\widehat{D}=$ GraySpace & -37.28 & 3 & 0.00 & 0.46 \\
\hline & $\widehat{D}=A v e d B$ & -37.74 & 3 & 0.94 & 0.29 \\
\hline \multirow[t]{5}{*}{ European Starling } & $\widehat{D}=$ Income & -91.73 & 3 & 0.00 & 0.24 \\
\hline & $\widehat{D}=$ GraySpace & -92.06 & 3 & 0.66 & 0.17 \\
\hline & $\widehat{D}=$ DistWood & -92.35 & 3 & 1.02 & 0.14 \\
\hline & $\widehat{D}=$ Income + DistWood & -91.15 & 4 & 1.46 & 0.12 \\
\hline & $\widehat{D}=$ Intercept $($ null $)$ & -93.87 & 2 & 1.83 & 0.10 \\
\hline
\end{tabular}


Table 6. Model-averaged regression coefficients (i.e., betas) for habitat variables included in density models. Estimated 95\% confidence intervals are included in parentheses below each estimate. Coefficients are bolded if $95 \%$ CIs do not include zero.

\begin{tabular}{|c|c|c|c|c|c|c|}
\hline Species & GraySpace & DistWood & AvedB & DistCore & DistPeriph & Income \\
\hline \multirow[t]{2}{*}{ Rock Pigeon } & 19.16 & -6.21 & -1.12 & -5.71 & 0.77 & 0.03 \\
\hline & $(0.80,37.51)$ & $(-17.24,4.82)$ & $(-1.98,-0.26)$ & $(-16.83,5.42)$ & $(-11.97,13.50)$ & $(-0.49,0.56)$ \\
\hline \multirow[t]{2}{*}{ Common Wood-Pigeon } & -4.98 & -0.71 & -0.11 & -0.97 & -0.55 & -0.01 \\
\hline & $(-7.21,-2.74)$ & $(-2.33,0.91)$ & $(-0.23,0.01)$ & $(-1.86,-0.08)$ & $(-1.43,0.33)$ & $(-0.09,0.07)$ \\
\hline \multirow[t]{2}{*}{ Eurasian Jackdaw } & -0.57 & 0.35 & -0.03 & -3.33 & -3.28 & 0.01 \\
\hline & $(-2.69,1.55)$ & $(-1.29,1.98)$ & $(-0.14,0.09)$ & $(-6.37,-0.30)$ & $(-5.95,-0.61)$ & $(-0.07,0.08)$ \\
\hline \multirow[t]{2}{*}{ Rook } & 3.94 & 1.25 & 0.16 & -1.21 & -0.78 & 0.00 \\
\hline & $(-0.48,8.37)$ & $(-2.22,4.72)$ & $(-0.09,0.40)$ & $(-3.95,1.53)$ & $(-4.13,2.58)$ & $(-0.17,0.17)$ \\
\hline \multirow[t]{2}{*}{ Hooded Crow } & -0.03 & -0.26 & -0.01 & 0.46 & 0.06 & 0.00 \\
\hline & $(-0.46,0.41)$ & $(-0.60,0.09)$ & $(-0.03,0.01)$ & $(0.09,0.83)$ & $(-0.31,0.43)$ & $(-0.01,0.02)$ \\
\hline \multirow[t]{2}{*}{ Eurasian Wren } & -1.38 & -0.88 & -0.07 & 0.34 & -0.31 & 0.00 \\
\hline & $(-2.40,-0.37)$ & $(-1.62,-0.15)$ & $(-0.12,-0.02)$ & $(-0.27,0.95)$ & $(-0.96,0.33)$ & $(-0.04,0.04)$ \\
\hline
\end{tabular}




\begin{tabular}{|c|c|c|c|c|c|c|}
\hline \multirow[t]{3}{*}{ European Starling } & -4.8 & 2.86 & -0.01 & -0.78 & -1.77 & 0.17 \\
\hline & $(-10.01$ & & & & & \\
\hline & $0.42)$ & $(-1.22,6.94)$ & $(-0.40,0.38)$ & $(-7.18,5.62)$ & $(-7.90,4.35)$ & $(-0.01,0.35)$ \\
\hline \multirow[t]{2}{*}{ Eurasian Blackbird } & -4.42 & -0.22 & -0.16 & -0.25 & -0.08 & 0.01 \\
\hline & $(-6.44,-2.40)$ & $(-1.94,1.50)$ & $(-0.32,-0.01)$ & $(-1.14,0.64)$ & $(-0.96,0.80)$ & $(-0.07,0.10)$ \\
\hline \multirow[t]{2}{*}{ House Sparrow } & 1.9 & 2.64 & 0.03 & -0.20 & 0.72 & 0.03 \\
\hline & $(-1.15,4.96)$ & $(0.63,4.65)$ & $(-0.15,0.21)$ & $(-3.11,2.71)$ & $(-1.37,2.81)$ & $(-0.08,0.14)$ \\
\hline
\end{tabular}


Table 7. Ranking of linear mixed effects models relating breeding bird species richness estimates with six urban habitat variables for 2016-2019 in Cork City, Ireland. See Table 1 for detailed descriptions of habitat variables.

\begin{tabular}{|c|c|c|c|c|}
\hline Model & $\log (L)$ & $\begin{array}{c}\text { No. of } \\
\text { parameters }\end{array}$ & $\Delta_{i}{ }^{\mathrm{a}}$ & $\begin{array}{c}\text { Akaike } \\
\text { weight } \\
\left(w_{i}\right)\end{array}$ \\
\hline$\hat{S}=$ DistPeriph + DistCore & -88.94 & 7 & 0.00 & 0.79 \\
\hline \multicolumn{5}{|l|}{$+A v e d B$} \\
\hline \multicolumn{5}{|l|}{ + GraySpace (PCA Dim.1) } \\
\hline$\hat{S}=$ GraySpace & -95.76 & 4 & 4.45 & 0.09 \\
\hline$\hat{S}=$ DistPeriph & -96.14 & 4 & 5.22 & 0.06 \\
\hline$\hat{S}=$ DistCore & -96.16 & 4 & 5.26 & 0.06 \\
\hline$\hat{S}=$ DistPeriph + DistCore & -88.78 & 9 & 7.19 & 0.02 \\
\hline \multicolumn{5}{|l|}{+ AvedB + Income } \\
\hline \multicolumn{5}{|l|}{ +GraySpace + DistWood } \\
\hline$\hat{S}=A v e d B$ & -98.98 & 4 & 10.90 & $<0.01$ \\
\hline$\hat{S}=$ Intercept $($ habitat $)$ & -102.85 & 3 & 16.00 & $<0.001$ \\
\hline
\end{tabular}




\begin{tabular}{|c|c|c|c|c|}
\hline$\hat{S}=$ DistWood & -101.61 & 4 & 16.16 & $<0.001$ \\
\hline$\hat{S}=$ Income + & -101.10 & 5 & 17.96 & $<0.0001$ \\
\hline \multicolumn{5}{|l|}{ DistWood (PCA Dim. 2) } \\
\hline$\hat{S}=$ Income & -102.83 & 4 & 18.60 & $<0.0001$ \\
\hline
\end{tabular}

${ }^{\mathrm{a}}$ Minimum $\mathrm{AIC}_{c}=196.54$ 
Figure captions:

Fig. 1 Map of 32 survey sites within Cork City, County Cork, Ireland. Commercial habitats (9 points) include shopping centers and business districts. Residential areas (11 points) include neighborhoods with single-family and multi-family housing. Managed habitats (12 points) include green spaces like city parks and school campuses. The River Lee is the major waterway through the center of the city.

Fig. 2 Ordination via principal component analysis (PCA) with bird detection data and nine habitat variables (defined in Table 1). The color gradient indicates low importance (blue; low $\cos 2$ ) to high importance (red; high $\cos 2$ ) of each species to the PCA.

Fig. 3 Estimated bird species richness estimates for Cork City during the breeding seasons of 2016-2019. Estimates are plotted against four urban habitat variables: (a) percentage gray space within $100 \mathrm{~m}$ of each survey point; (b) distance $(\mathrm{km})$ from each point to the urban periphery; (c) distance $(\mathrm{km})$ from each point to the urban core; and (d) average urban noise pollution $(\mathrm{dB})$ levels at each point. All variables are described in detail in Table 1. The gray shaded regions represent $95 \%$ confidence intervals

Fig. 4 Non-metric multidimensional scaling (NMDS) ordination of the numbers of detections by species (NMDS1) versus the three urban habitat categories (NMDS2; red represents commercial regions, orange represents residential areas, and green represents managed habitats) 


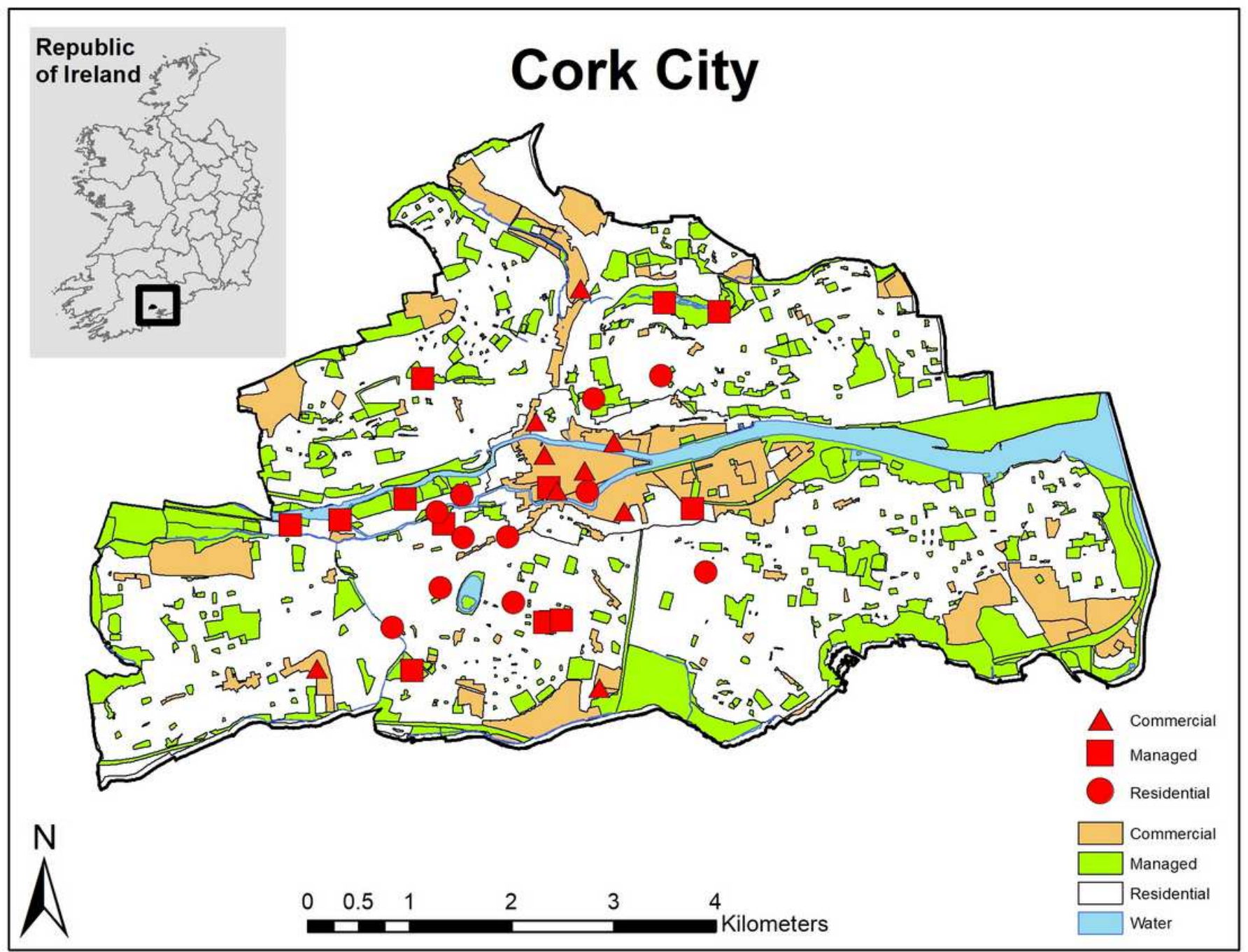

\section{Figure 1}

Map of 32 survey sites within Cork City, County Cork, Ireland. Commercial habitats (9 points) include shopping centers and business districts. Residential areas (11 points) include neighborhoods with singlefamily and multi-family housing. Managed habitats (12 points) include green spaces like city parks and school campuses. The River Lee is the major waterway through the center of the city. Note: The designations employed and the presentation of the material on this map do not imply the expression of any opinion whatsoever on the part of Research Square concerning the legal status of any country, territory, city or area or of its authorities, or concerning the delimitation of its frontiers or boundaries. This map has been provided by the authors. 


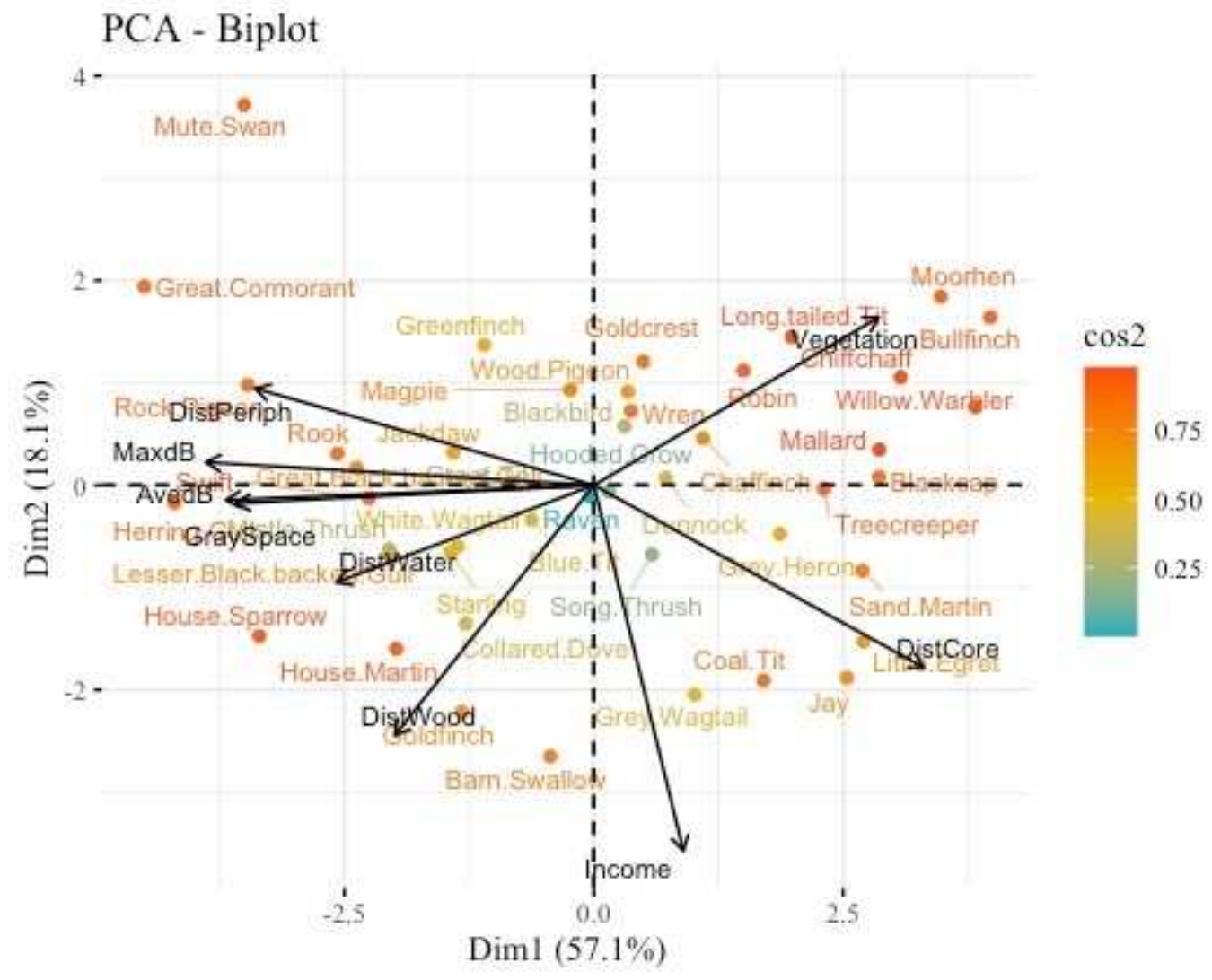

Figure 2

Ordination via principal component analysis (PCA) with bird detection data and nine habitat variables (defined in Table 1). The color gradient indicates low importance (blue; low cos2) to high importance (red; high cos2) of each species to the PCA. 


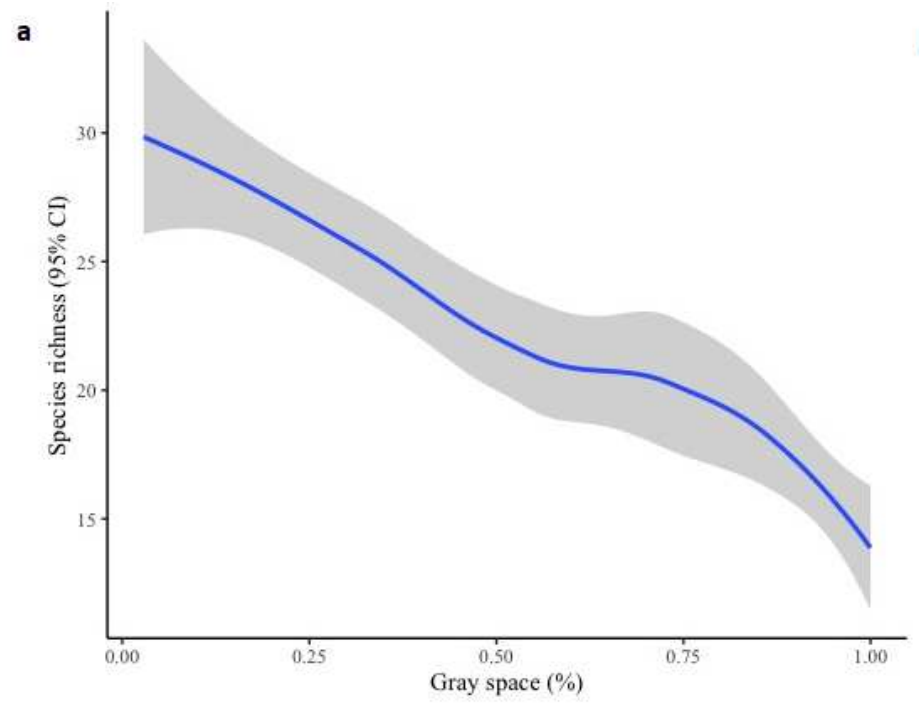

b


Figure 3

Estimated bird species richness estimates for Cork City during the breeding seasons of 2016-2019. Estimates are plotted against four urban habitat variables: (a) percentage gray space within $100 \mathrm{~m}$ of each survey point; (b) distance $(\mathrm{km})$ from each point to the urban periphery; (c) distance $(\mathrm{km})$ from each point to the urban core; and $(\mathrm{d})$ average urban noise pollution $(\mathrm{dB})$ levels at each point. All variables are described in detail in Table 1. The gray shaded regions represent $95 \%$ confidence intervals 


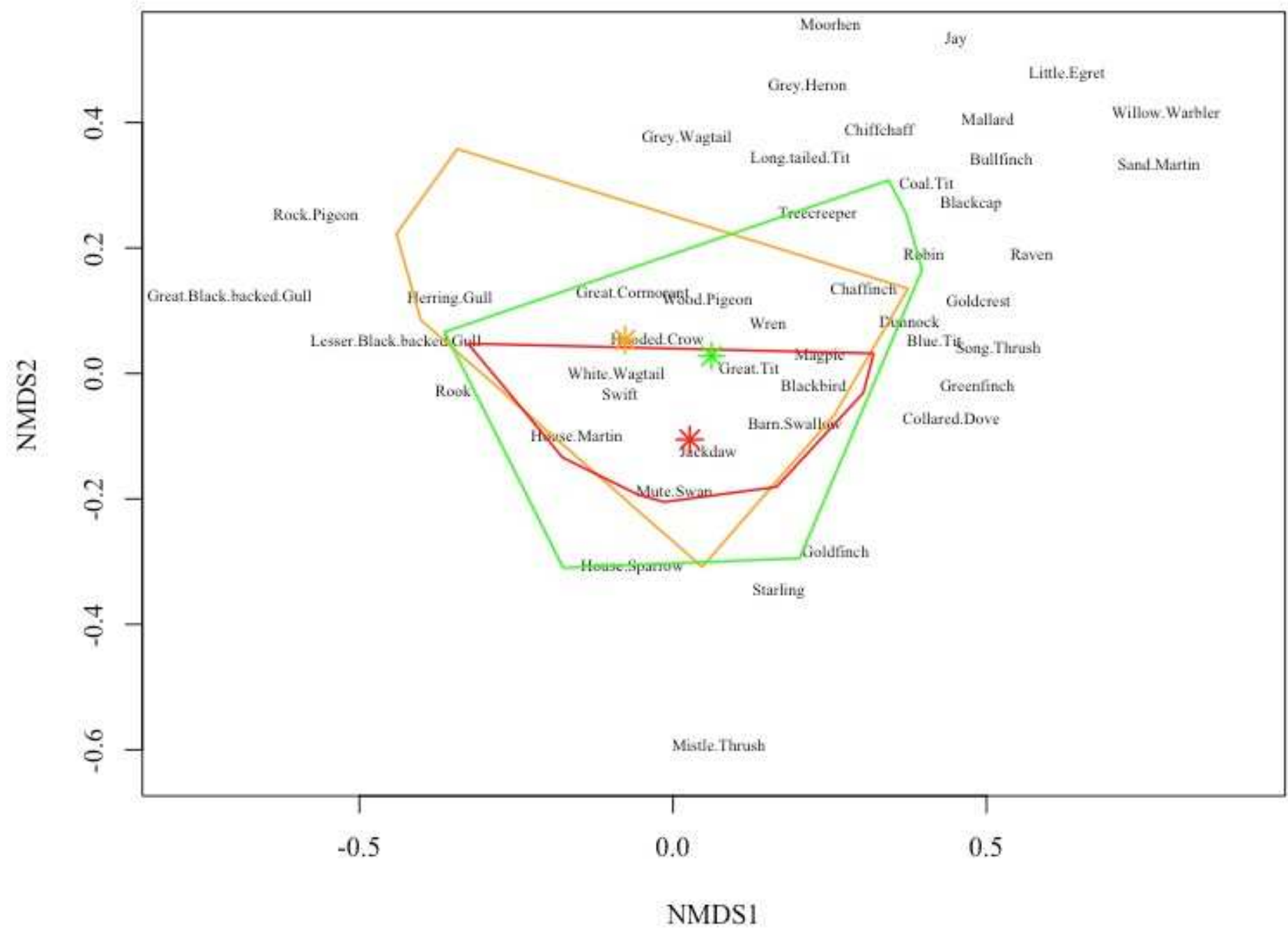

\section{Figure 4}

Non-metric multidimensional scaling (NMDS) ordination of the numbers of detections by species (NMDS1) versus the three urban habitat categories (NMDS2; red represents commercial regions, orange represents residential areas, and green represents managed habitats) 